\title{
EFFICACY OF HARVEST-AID DEFOLIANTS ON YIELD OF SEED COTTON (GOSSYPIUM HIRSUTUM L.)
}

\author{
Kulvir Singh* and Pankaj Rathore \\ Punjab Agricultural University, Regional Research Station, \\ Faridkot-151203, Punjab, India
}

Key words: Efficacy, Harvest-aid, defoliants, Seed cotton yield, Water productivity

\begin{abstract}
Field experiments were conducted to determine the effect of different harvest-aid defoliants, their application rates and time of application [140 and 150 days after sowing (DAS)] on yield of seed cotton (Gossypium hirsutum L.). MRC7361BGII (3171.8 kg/ha) and MRC7017BGII (3083.3 kg/ha) produced significantly higher yield as compared to F1861 (2454.9 kg/ha). Improved water and fertilizer use efficiency coupled with better Benefit: Cost (B : C) ratio for Dropp ultra $200 \mathrm{ml} / \mathrm{ha}$ at $150 \mathrm{DAS}$ clearly indicated its superiority over other treatments. Dropp ultra showed potential to improve yield besides promoting crop earliness while keeping vegetative and reproductive growth in harmony.
\end{abstract}

The cotton plant is a perennial with an indeterminate growth habit and reputed to have the most complex growth habit of all major row crops (Oosterhuis 1999). One challenge of producing cotton (Gossypium hirsutum L.) in the north-western Indian cotton belt is to get the crop matured within a defined period prior to commencement of Rabi season in November. In this region, producers seek to shift cotton from vegetative to reproductive growth in mid-season to assure adequate time for bolls to mature and consequently timely sowing of wheat. Use of harvest-aid defoliants may be helpful in this regard. In developed countries, defoliants have been widely used in cotton production for adjusting plant growth and improve lint yield and fiber quality (ElKassaby and Kandil 1985, Larson et al. 2002). In the present work, it was intended to study the effect of harvest-aid defoliants on seed cotton yield and also identify suitable defoliant with optimum dose along with ideal time of application to realize high productivity and to study their economic viability.

The experiment was conducted during Kharif 2011 and 2012 at Punjab Agricultural University, Regional Research Station, Faridkot which lies in Trans-Gangetic agro-climatic zone, representing the Indo-Gangetic alluvial plains $\left(30^{\circ} 40^{\prime} \mathrm{N}\right.$ and $\left.74^{\circ} 44^{\prime} \mathrm{E}\right)$ of Punjab situated at $200 \mathrm{~m}$ above mean sea level. The soil of the experimental field was sandy loam, with normal $\mathrm{pH}(8.04)$, EC $(0.22 \mathrm{dS} / \mathrm{m})$, O.C $(0.51 \%)$, medium in available $\mathrm{P}(16 \mathrm{~kg} / \mathrm{ha})$ but high in available $\mathrm{K}(515$ $\mathrm{kg} / \mathrm{ha}$ ). The experiment comprising of three high-yielding cultivars (F1861, MRC7361BGII and MRC7017BGII) in main, four defoliants [Control; Dropp ultra i.e \{Thiadiuron 36\% SC + Diuron 18\% SC $200 \mathrm{ml} / \mathrm{ha}$; Dropp ultra $225 \mathrm{ml} / \mathrm{ha}$ and Ethrel \{2-chloro ethyl phosphonic acid\} @ 2000 ppm] in sub and two times of application (140 and 150 DAS) in sub sub plots was conducted in split plot design replicated thrice. Total amount of rainfall was 575.8 and $223.6 \mathrm{~mm}$ for the year 2011 and 2012, respectively. Total rainy days (41) were higher during 2011 as compared to only 28 days in the year 2012. A total of 6 and 7 irrigations were applied during 2011 and 2012, respectively to raise the crop successfully. A maximum temperature of $40.9^{\circ} \mathrm{C}$ was recorded in May 2011, while June $\left(40.7^{0} \mathrm{C}\right)$ was the hottest month in 2012. Sowing was performed as on

*Author for correspondence: <kulvir@pau.edu>. 
16.5.2011 and 17.5.2012 at a uniform row spacing of $67.5 \mathrm{~cm}$. Each plot size measuring $4.05 \times$ $6 \mathrm{~m}$ had 54 plants $(67.5 \times 75 \mathrm{~cm})$ per treatment. A recommended fertilizer dose of $150 \mathrm{~kg} \mathrm{~N}, 30 \mathrm{~kg}$ $\mathrm{P}_{2} \mathrm{O}_{5}, 50 \mathrm{~kg} \mathrm{~K} 2 \mathrm{O}$ and $25 \mathrm{~kg} \mathrm{ZnSO}_{4}(21 \%)$ per hectare was uniformly applied (Anon. 2013). All other agronomic practices were followed as per recommended package of practices. Dropp ultra concentration of 0.066 and $0.075 \%$, respectively for 200 and $250 \mathrm{ml} /$ ha were made and delivered uniformly using a knapsack sprayer with water @ $300 \mathrm{l} / \mathrm{ha}$. Seed cotton yield $(\mathrm{Kg} / \mathrm{ha})$ was recorded from whole plot excluding border rows. Water and fertilizer use efficiency was worked out for each year by dividing the seed cotton yield with total amount of irrigation water and fertilizer applied for the respective parameter. Production cost was calculated by adding cost of all the fixed inputs (i.e. pre-sowing tillage operations, sowing, interculture, fertilizers, pesticides and other chemicals, labour used for irrigation, sprays and finally picking etc.). Economics was calculated on the basis of prevailing market price of inputs and seed cotton. The data were analyzed statistically as per the standard procedure (Cheema and Singh 1991). Pooled means have been used to discus results.

Defoliation in cotton plant depends mainly on environmental, as well as genetic factors and cultivation techniques (Whitwell et al. 1987). The pooled results (Table 1) revealed that MRC7361BGII (3171.8 kg/ha) and MRC7017BGII $(3083.3 \mathrm{~kg} / \mathrm{ha})$ produced significantly higher seed cotton yield (SCY) as compared to F1861 (2454.9 kg/ha) due to better bolls/plant and boll weight. Significantly higher fertilizer use efficiency (FUE) by 29.1 and 25.5 per cent was recorded under MRC7361BGII (6.78) and MRC7017BGII (6.59) as compared to F1861 (5.25). Likewise, water productivity (WP) was clearly in favour of MRC7361BGII (655.9) and MRC7017BGII (637.6) as compared to F1861 (506.2). Cost of cultivation in case of F1861 (₹25252 /ha) was significantly low primarily due to low seed cost of variety as compared to other $B t$ hybrids and also low SCY as a result of which less picking labour was employed. Statistically better net returns clearly reflected superiority for MRC7361BGII (₹75544 /ha) and MRC7017BGII (₹72931/ha). Furthermore, an improved B : C ratio in case of MRC7361BGII (2.50) and MRC7017BGII (2.44) over that of F1861 (2.27) substantiated this finding (Table 2). Nagwekar et al. (1984) also observed variability among cotton varieties in respect of yield and fiber quality characteristics with defoliation treatments. Thakral et al. (1991) reported similar findings.

Dropp ultra $200 \mathrm{ml} / \mathrm{ha}$ exhibited significantly better SCY (3111.6 kg /ha) as compared to higher dose of $225 \mathrm{ml} / \mathrm{ha}(2674.5 \mathrm{~kg} / \mathrm{ha})$ as well as Ethrel 2000ppm (2948.3 kg /ha) and control (2878.9 kg /ha). Pooled data indicated increase in SCY by 8.1, 16.3 and 5.53 per cent over control, Dropp ultra $225 \mathrm{ml} / \mathrm{ha}$ and Ethrel, respectively (Table 1). However, Weir and Gaggero (1982) reported $51 \%$ open bolls, compared with only $22 \%$ for control with ethrel application. Application of Dropp ultra $225 \mathrm{ml} / \mathrm{ha}$ resulted in severe shedding of leaves, young flowers and fruiting bodies and even some developing bolls, which lead to significant reduction in seed cotton as well as lint yield. FUE was also significantly reduced with Dropp ultra $225 \mathrm{ml} / \mathrm{ha}$ (5.72) as compared to all other treatments. However, significantly highest FUE (6.65) was observed with Dropp ultra 200 $\mathrm{ml} / \mathrm{ha}$, which indicated its positive influence on SCY and other monetary parameters. Water productivity also exhibited strong favor for Dropp ultra $200 \mathrm{ml} / \mathrm{ha}$ (643.1) followed by Ethrel (609.2) and control (594.6). Statistically least WP $\left(552.7 \mathrm{~g} / \mathrm{m}^{3}\right)$ was recorded with the application of Dropp ultra225 ml/ha owing to reasons mentioned above. Significantly highest (₹29398/ha) and lowest (₹27769/ha) cost of cultivation was recorded with Dropp ultra $200 \mathrm{ml}$ and $225 \mathrm{ml} / \mathrm{ha}$, respectively. This was directly related with SCY and labour charges associated with the picking. Significantly highest net returns of $₹ 74682$ /ha were recorded with application of Dropp ultra 200 $\mathrm{ml} / \mathrm{ha}$ followed by Ethrel (₹69846/ha), control (₹67806/ha) with statistically least value (₹61701/ha) under Dropp ultra $225 \mathrm{ml} / \mathrm{ha}$. Better B:C ratio with Dropp ultra $200 \mathrm{ml}$ (2.55) and Ethrel (2.43) over Dropp ultra $225 \mathrm{ml} / \mathrm{ha} \mathrm{(2.23)} \mathrm{clearly} \mathrm{indicated} \mathrm{their}$ 


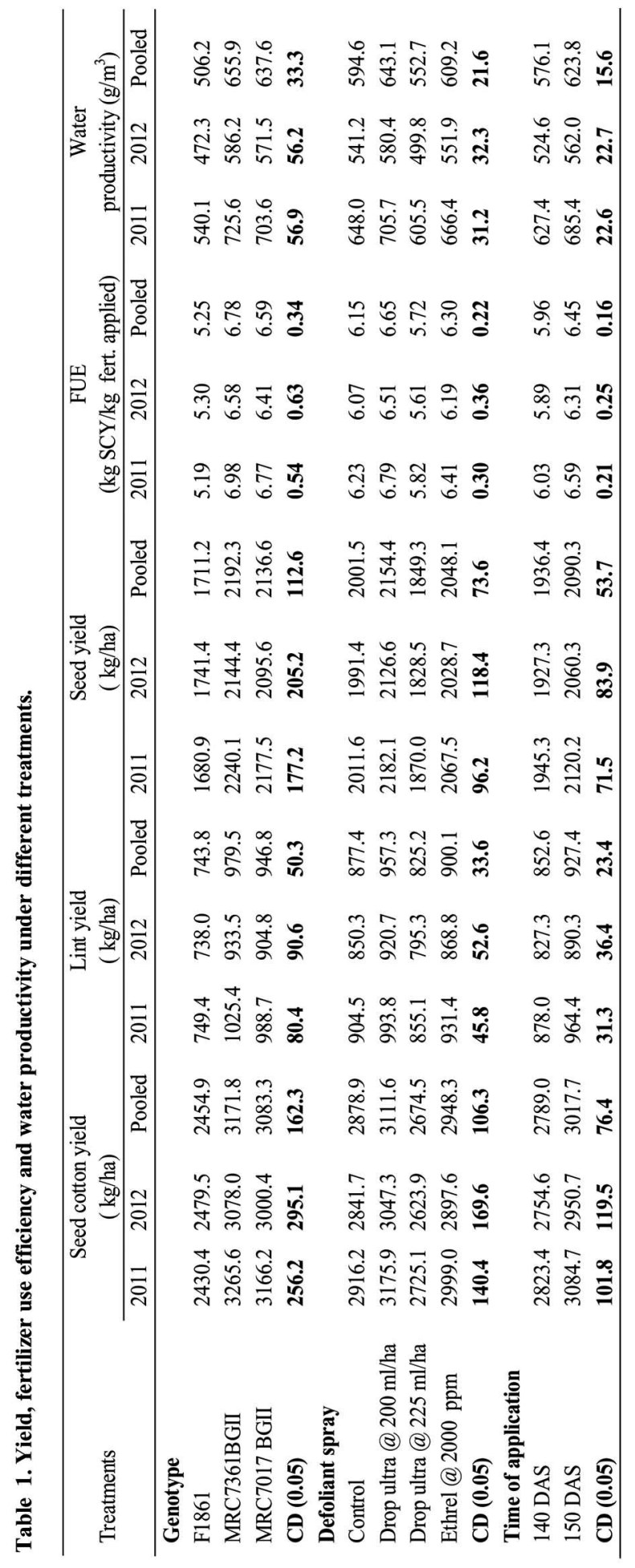




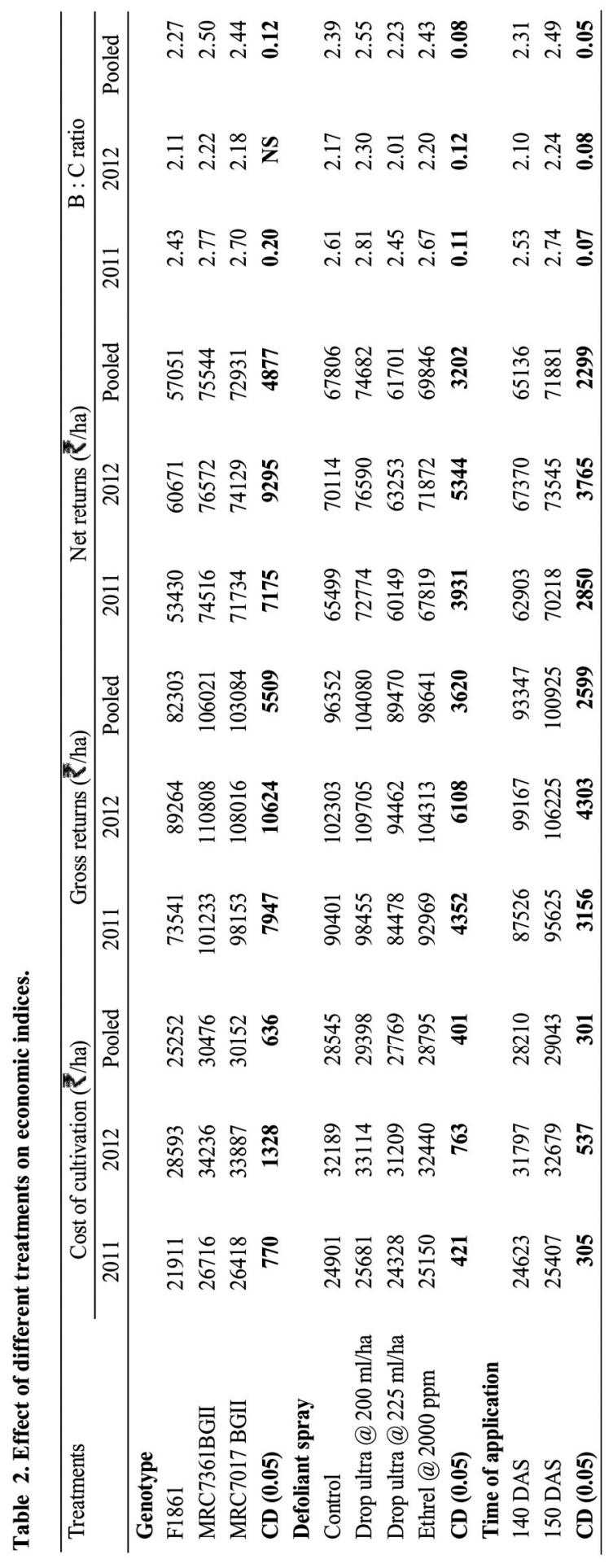


economic superiority (Table 2). Lint yield was statistically improved under later $(927.4 \mathrm{~kg} / \mathrm{ha}$ ) as compared to early application $(852.6 \mathrm{~kg} / \mathrm{ha}$ ) primarily due to better boll retention and consequently less shedding under later application. Similar results were reported by (O_lakçi and Kaynak 1992, Locke et al. 1995 and Faircloth et al. 2004).

In the present studies, early application (140 DAS) lead to severe shedding of young squares, flowers, fruiting bodies and even younger bolls. Therefore, significantly better SCY was observed with later application at 150 DAS (3017.7 kg/ha) over the early application $(2789.0 \mathrm{~kg} / \mathrm{ha})$. These results showed that SCY was significantly and negatively affected by early defoliation. One possible explanation is that postponing defoliation allows for more carbon assimilation and partitioning of photo assimilates to develop cotton bolls. These results are in agreement with findings of other workers (Snipes and Baskin 1994, Larson et al. 2002, Çiçek et al. 2003 and Karademir et al. 2007). Çopur et al. (2010) also found that delaying crop termination with Dropp ultra and Round up defoliants recorded better boll formation and yield than control. Significant improvement in FUE (6.45) and WP (623.8) in delayed application at 150 DAS of various harvestaid defoliants clearly supported enhanced SCY over the early application. Though cost of cultivation in later application was merely higher by ₹833/ha primarily owing to high picking charges for enhanced SCY but net returns indicated an additional benefit of ₹ $6745 /$ ha. Significant improvement in B : C ratio under later (2.49) over the earlier (2.31) application substantiated these findings (Table 2). It is concluded that application of Dropp ultra $200 \mathrm{ml} / \mathrm{ha}$ at 150 DAS can promote earliness in cotton while maintaining an equilibrium in vegetative and reproductive growth and therefore, should be considered a useful production practice for enhancing seed cotton yield under semi-arid conditions.

\section{References}

Anonymous. 2013. Punjab Agricultual University Ludhiana. Package of practices for Kharif Crops. pp.38-61.

Cheema HS and Singh B 1991. Software: Statistical package CPCS-1 Department of Math, Statistics and Physics; Punjab Agricultural University, Ludhiana.

Çiçek B, O_lakçi M, and Çopur O 2003. Effect of defoliation on cotton (Gossypium hirsutum L.) yield and quality components. J. Fac. Agric. 7: 45-52.

Çopur Osman, Ufuk Demirel, Refik Polat and Mehmet Atilla Gür 2010. Effect of different defoliants and application times on the yield and quality components of cotton in semi-arid conditions. Afric. J. Biotechnol. 9: 2095-2100.

El-Kassaby AT and Kandil TAA 1985. Effect of defoliants and nitrogen fertilization on Egyptian cotton yield (Gossypium barbadense L.). (Mansoura University, Egypt). J. Agric. Sci. 10:23-31.

Faircloth JC, Edmisten KL, Wells R and Stewart AM 2004. The influence of defoliation timing on yield and quality of two cotton cultivars. Crop Sci. 44: 165-172.

Karademir E, Karademir C and Basbag S 2007. Determining the effect of defoliation timing on cotton yield and quality. J. Central Europ. Agric. 8: 357-362.

Larson JA, Gwathmey CO and Hayes RM 2002. Cotton defoliation and harvest timing effects on yields, quality and net revenues. J. Cotton Sci. 6:13-27.

Locke D, Landivar JA and Moseley D 1995. The Effects of rate and timing glyphosate applications on defoliation efficiency, re-growth inhibition, lint yield, fiber quality and seed quality. Beltwide Cotton Conferences, National Cotton Council, San Antonio, Texas, USA. pp. 1088-90.

Nagwekar SN, Yadav BD and Lather BPS 1984. Effect of defoliation of American cotton varieties 320-F and H.655 in respect of yield and fiber quality characteristics. Cotton Devp. 14: 33-35.

O_lakçi M and Kaynak MA 1992. Harvest-aid chemical applications in cotton cultivation. J. Fac. Agric. 3: 78-83. 
Oosterhuis DM 1999. Yield response to environmental extremes in cotton. pp. 30-38. In: Oosterhuis, D.M. (ed.) Proc. 1999 Cotton Research Meeting Summary Cotton Research in Progress. Report 193. Arkansas Agric. Exp. Stn., Fayetteville, AR.

Snipes CE and Baskin CC 1994.Influence of early defoliation on cotton yield, seed quality and fiber properties. Field Crop Res. 37: 137- 143.

Thakral SK, Bishnoi LK, Surinder S and Singh S 1991. Effect of defoliant on upland cotton (Gossypium hirsutum L.). Indian J. Agric. Sci. 61: 772-774.

Weir Bill L and Gaggero JM 1982.Ethephon may hasten cotton boll opening, increase yield. California Agric. Ext. Stn. 36: 28-29.

Whitwell T, Brown SM and Mcguire JA 1987. Influence of application date on harvest aids for cotton. Appl. Agri. Res. 2: 15-19.

(Manuscript received on 23 March, 2013; revised on 16 October, 2014) 